\title{
Damage control in the intensive care unit: what should the intensive care physician know and do?
}

\section{Control de daños en la unidad de cuidados intensivos: ¿qué debe conocer y hacer el médico intensivista?}

\author{
Mónica Varạas $^{1}$ Alberto García ${ }^{2,3,4}$ (D) Yaset Caicedo ${ }^{5}$ Michael W. Parra ${ }^{6}$ (D) Carlos A. \\ Ordoñez $2,3,4$ (i) \\ ordonezcarlosa@gmail.com, carlos.ordonez@fvl.org.co
}

1 Fundación Valle del Lili, Department of Intensive Care, Cali, Colombia, 2 Fundación Valle del Lili, Department of Surgery, Division of Trauma and Acute Care Surgery, Cali, Colombia $\mathbf{3}$ Universidad del Valle, Facultad de Salud, Escuela de Medicina, Department of Surgery, Division of Trauma and Acute Care Surgery, Cali, Colombia 4 Universidad ICESI, Cali, Colombia 5 Fundación Valle del Lili, Centro de Investigaciones Clínicas (CIC), Cali, Colombia, 6 Broward General Level I Trauma Center, Department of Trauma Critical Care, Fort Lauderdale, FL - USA

Citation: Vargas M, García A, Caicedo Y, Parra MW, Ordoñez CA. Damage control in the intensive care unit: what should the intensive care physician know and do? Colomb Méd (Cali), 2021; 52(2):e4174810

http://doi.org/10.25100/ cm.v52i 2.4810

Received : 01 Apr 2021

Revised: 13 May 2021

Accepted : 02 Jun 2021

Published: 30 Jun 2021

Keywords:

Damage control, hemorrhagic shock, resuscitation, Hypothermia, Blood Coagulation Disorders, Hemorrhage, Critical Care, Intensive Care Units, Acidosis

\section{Palabras clave:}

Control de daños, choque hemorrágico, resucitación, coagulopatía, hipotermia, hemorragia, cuidado critico, unidad de cuidados intensivos, acidosis

Copyright: () 2021 Universidad del Valle (c) (7)

\section{Abstract}

When trauma patients are admitted into the intensive care unit after undergoing damage control surgery, they generally present some degree of bleeding, hypoperfusion, and injuries that require definitive repair. Trauma patients admitted into the intensive care unit after undergoing damage control surgery can present injuries that require a definite repair, which can cause bleeding and hypoperfusion. The intensive care team must evaluate the severity and systemic repercussions in the patient. This will allow them to establish the need for resuscitation, anticipate potential complications, and adjust the treatment to minimize trauma-associated morbidity and mortality. This article aims to describe the alterations present in patients with severe trauma who undergo damage control surgery and considerations in their therapeutic approach. The intensivist must detect the different physiological alterations presented in trauma patients undergoing damage control surgery, mainly caused by massive hemorrhage. Monitor and support strategies are defined by the evaluation of bleeding and shock severity and resuscitation phase in ICU admission. The correction of hypothermia, acidosis, and coagulopathy is fundamental in the management of severe trauma patients.

\section{Resumen}

Cuando el paciente de trauma ingresa a la unidad de cuidado intensivo después de una cirugía de control de daños, generalmente aún presenta algún grado de hemorragia, hipoperfusión y lesiones que requieren reparo definitivo. La evaluación por parte del intensivista del grado de severidad de tales alteraciones, y las repercusiones sistémicas, permitirán establecer las necesidades de reanimación, prever potenciales complicaciones y hacer los ajustes al tratamiento con el fin de minimizar la morbilidad y mortalidad asociada al trauma. El objetivo de este artículo es describir las alteraciones que presentan los pacientes con trauma severo manejados con cirugía de control de daños y las consideraciones a tener en cuenta para su abordaje terapéutico. Se presentan los aspectos más relevantes del manejo del paciente con trauma severo 


\section{Conflicts of interest:}

The authors declare that they have no conflict of interest.

\section{Acknowledgements:}

We acknowledge Isabella CaicedoHolguín and Isabella Caicedo-Muriel for their contributions to the writing of this manuscript.

\section{Corresponding author:}

Carlos A. Ordonez, MD, FACS. Division of Trauma and Acute Care Surgery, Department of Surgery. Fundación Valle del Lili. Cali, Colombia; Division of Trauma and Acute Care Surgery, Department of Surgery, Universidad del Valle, Cali, Colombia; Universidad Icesi, Cali, Colombia. Email: ordonezcarlosa@gmail.com, carlos.ordonez@fvl.org.co y cirugía de control de daños a su ingreso a la UCI. El intensivista debe conocer las alteraciones fisiológicas que puede presentar el paciente de trauma sometido a cirugía de control de daños, especialmente las causadas por la hemorragia masiva. La evaluación de estas alteraciones, de la severidad del sangrado y del estado de choque, y estimar en qué punto de la reanimación se encuentra el paciente a su ingreso a la unidad de cuidados intensivos son fundamentales para definir la estrategia de monitoria y soporte a seguir. La corrección de la hipotermia, la acidosis y la coagulopatía es la prioridad en el tratamiento del paciente con trauma severo.

\section{Remark}

\section{1) Why was this study conducted?}

When the patient is admitted into the ICU, the physician should identify all the physiological alterations to establish resuscitation management goals. These strategies allow an early correction of trauma-induced coagulopathy and hypoperfusion increasing the likelihood of survival. The objective of this article is to describe the physiological alterations in a severely injured trauma patient who undergo damage control surgery and to establish an adequate management approach.

\section{2) What were the most relevant results of the study?}

The severely injured trauma patient who undergoes damage control surgery and is admitted to the Intensive Care Unit should always have a comprehensive evaluation that allows the physician to identify all the physiological alterations and establish the resuscitation management goals. These strategies allow an early correction of trauma-induced coagulopathy and hypoperfusion increasing the likelihood of survival.

\section{3) What do these results contribute?}

The physician should always be aware and correct the hypothermia, acidosis, coagulopathy and hypocalcemia presented in the severely injured trauma patients.

\section{Introduction}

Damage control surgery has transformed the management of severely injured trauma patients. It was initially described as a three-step process that included an abbreviated initial surgery for bleeding and contamination control, aggressive resuscitation in the intensive care unit (ICU) and then deferred definitive repair ${ }^{1}$. These principles have been subsequently used in surgical approaches for vascular, orthopedic, and thoracic injuries ${ }^{2-4}$. The objective of the damage control strategy is to rapidly control life-threatening injuries and reverse physiological alterations such as acidosis, hypothermia, and coagulopathy (the triad of death). Then a deferred definitive repair should be performed.

One of the main causes of trauma-related mortality is uncontrolled bleeding. Hemorrhagic shock leads to tissue hypoperfusion and physiological alterations that ultimately cause organ dysfunction and death. Consequently, damage control surgery must be directed to massive bleeding control ${ }^{5}$. 
When a patient is admitted into the ICU, shock and physiological alterations must be identified and corrected. The biggest challenge is to identify if the bleeding is secondary to the injury itself or to the trauma-induced coagulopathy. The early implementation of the strategies to evaluate and correct the trauma-associated disorders improves the prognosis of the severely injured patient ${ }^{6}$. Once resuscitation has been completed, the patient should be taken back to surgery for definitive repair. The objective of this article is to describe the experience obtained by our group in the ICU management of severely injured trauma patients who undergo damage control surgery.

This article is a consensus that synthesizes the experience earned during the past 30 years in trauma critical care management of the severely injured patient from the Trauma and Emergency Surgery Group (CTE) of Cali, Colombia which is made up of experts from the University Hospital Fundación Valle del Lili, the University Hospital del Valle "Evaristo García", the Universidad del Valle and Universidad Icesi, the Asociación Colombiana de Cirugia, the Pan-American Trauma Society and the collaboration of international specialists of the United States of America, Europe, Japan, South Africa, and Latin America.

\section{Resuscitation in ICU}

\section{Initial Evaluation}

Once the patient is transferred to the ICU after damage control surgery it is of utmost importance to evaluate the severity of shock. Therefore, extensive laboratory testing and close monitoring of the hematologic, hemodynamic, and respiratory systems should be performed. We propose the following management (Table 1).

\section{Acid-base status}

Severe trauma patients are usually admitted to the ICU with severe metabolic acidosis and hypothermia. Metabolic acidosis alters platelet function, coagulation factors, and thrombin generation. These conditions increased the mortality rate with a greater need for blood products transfusion ${ }^{7,8}$. Some studies have shown that a $\mathrm{pH}$ of 7.1 or less is the limit for a severe coagulation pathway compromise ${ }^{9}$. Also, a base excess (BE) of -12.5 or less has been considered as a sensitive measure of inadequate perfusion (10). When tissue perfusion is restored, these parameters will be corrected.

\section{Temperature}

A temperature below $34^{\circ} \mathrm{C}$ increases the mortality rate of severely injured trauma patients, the mortality is almost $100 \%$ when a temperature of $32^{\circ} \mathrm{C}$ or lower is reached. A decrease in body temperature causes alterations in platelet function, coagulation proteases, and fibrinolytic activity ${ }^{11}$. Therefore, hypothermia induces trauma-induced coagulopathy, which is like a coagulation factor deficiency state ${ }^{12}$. The main cause of hypothermia in severely injured trauma

Table 1. Management of the trauma patient undergoing damage control surgery in Intensive Care Unit

\begin{tabular}{ll}
\hline Management & Intervention \\
\hline Assessment of Acid-Base status & Serial monitoring of blood gases \\
Correction of Hypothermia & Warmed Fluids \\
& Active rewarming strategies \\
Reversal of Coagulopathy & Massive Transfusion Protocol \\
& Transfusion therapy guided by viscoelastic tests (TEG / ROTEM) \\
Correction of electrolytes disturbances & Monitoring and correction of hypocalcemia (Calcium Ion 1.1-1.3 mmol/L) \\
& Monitoring and correction of hypercalcemia \\
Assessment of Tissular Perfusion & Hemodynamic status \\
& Tissular perfusion markers (Lactate and Base Excess) \\
& Vasopressor and inotropic support \\
\hline
\end{tabular}


patients is the administration of large amounts of cold intravenous fluids. Fluid resuscitation should be limited to maintain a mean arterial pressure $\geq 65 \mathrm{mmHg}$ and a systolic blood pressure $>90 \mathrm{mmHg}$. Hypothermia has also been associated with some complications such as bradycardia, first-degree atrioventricular block, prolonged QT, surgical site infection, and/or pneumonia ${ }^{13-15}$. Therefore, the physician should ensure its early identification and management.

\section{Anemia}

Platelets play an important role in coagulation reactions, which are important to the injured endothelium. Where tissue factor is exposed, the platelets adhere and aggregate themselves ${ }^{16}$. Under normal conditions, platelets are ejected to the marginal layer closer to the blood vessel wall due to the interaction with erythrocytes in their number and size ${ }^{17}$. Platelet activation and adhesion depend on the adenosine diphosphate (ADP) of red blood cells and are inhibit with decreased hematocrit levels ${ }^{18}$. In severely injured trauma patients, the hemorrhage and the large volumes of fluids have a significant effect on hematocrit and hemostasis. Some studies demonstrate that the coagulation pathways are disturbed before tissue hypoxia ${ }^{19}$. Therefore, the resuscitation with normal platelet and hematocrit levels is the initial objective to restore hemostasis $^{20}$.

\section{Calcium}

A calcium level below $0.9 \mathrm{mmol} / \mathrm{L}$ has been related to increased mortality rates (Normal Ionized calcium levels are between 1.1 to $1.3 \mathrm{mmol} / \mathrm{L}$ ). Hypocalcemia causes life-threatening rhythm disorders of the heart and coagulation pathway dysfunction due to its function in clotting factors recruitment, fibrinogen to fibrin conversion, platelet and C-reactive protein activation, among others ${ }^{21,22}$. The main causes of hypocalcemia are hemodilution and citrate-containing blood products. This condition is aggravated by shock and ischemia-reperfusion ${ }^{23-25}$.

\section{Hemodynamic status and tissue perfusion}

The severity of shock should be determined to establish resuscitation goals in the severely injured trauma patient undergoing damage control surgery. Bleeding control is the priority, it reverses the hypoperfusion state and organic failure of the patient ${ }^{26}$. At the same time, minimum perfusion levels and permissive hypotension should be established to avoid hemorrhage exacerbation (systolic blood pressure between $60-90 \mathrm{mmHg}$ ) ${ }^{27}$. Once bleeding has been controlled, the hemodynamic status of the patient should be assessed. Blood pressure and heart rate have been traditionally used to estimate the degree of hypovolemia according to the Advanced Trauma Life Support (ATLS) classification. However, these parameters have a low sensitivity in young patients and should not be used as an isolated reference ${ }^{28}$. Up to $85 \%$ of the severely injured trauma patients with normal hemodynamic parameters could have occult hypoperfusion with persistently increased BE or lactate levels ${ }^{29-35}$. Therefore, the implementation of the tissue perfusion (BE and lactate levels) with the hemodynamic parameters contribute to a better physiological status assessment of the patient and adequate resuscitation guidance.

\section{Coagulation}

The causes of coagulopathy in patients with severe trauma are multifactorial. Two categories are recognized: trauma-induced coagulopathy and resuscitation-related coagulopathy ${ }^{36}$. Around 25 to $35 \%$ of the trauma patients had acute trauma-induced coagulopathy on admission due to tissue damage and shock. This disorder is a hypercoagulable state produced by endogenous anticoagulant activity (endogenous heparinization, C-reactive protein activation, hyperfibrinolysis, and platelet dysfunction) that at the microvascular level counteracts the procoagulant condition ${ }^{37,38}$. 
The resuscitation-related coagulopathy is caused by the dilution of coagulation factors due to fluid resuscitation and/or coagulation dysfunction secondary to hypocalcemia, acidosis or hypothermia ${ }^{39}$. A rapid and reliable diagnosis of coagulopathy is crucial. There are two types of tests, the standard coagulation tests (prothrombin time, partial thromboplastin time, International normalized ratio , fibrinogen level, and platelet count), and the viscoelastic tests (Thromboelastography, Thromboelastometry). The standard coagulation tests have limited ability to reveal the coagulation status in vivo, therefore are poor predictors and do not provide a realistic target for resuscitation ${ }^{40,41}$. Whereas some evidence shows that viscoelastic testing is superior for coagulation disturbances detection in trauma patients ${ }^{42}$. It is important to notice that neither of these tests reflects the effect of hypothermia on coagulation since both are performed at $37^{\circ} \mathrm{C}^{9}$.

\section{Resuscitation strategy}

Once the physiological alterations have been identified, the resuscitation should be directed. The recommendation for the management of hypothermia is the implementation of active rewarming strategies with a surface, intravascular, air and/or fluid warming devices.

Hypocalcemia management has been recognized as a critical factor for resuscitation in the "Lethal Diamond" proposal ${ }^{43}$. Although a defined consensus is not yet available, it is recommended an early administration of calcium to ensure levels between 1 and $1.2 \mathrm{mmol} / \mathrm{L}$, starting with 1 gram of calcium chloride or its equivalent in calcium gluconate after the transfusion of the first 4 units of blood components. Then, the correction of the calcium level should be based on serial monitoring of the ionized calcium levels ${ }^{44}$.

The main cause of acidosis in trauma patients is hypoperfusion. The volume should be optimized via the administration of intravenous fluids, blood components, vasopressors, and inotropic support. These are the main pillars of resuscitation management. Additionally, hemodynamic optimization is associated with the coagulopathy correction following the hemostatic resuscitation strategy. Initially, the institutional massive transfusion protocol should be activated, which is usually started with packed red blood cells and fresh frozen plasma in a 1:1 ratio and then platelets and cryoprecipitate ${ }^{46}$.

Holcomb et al. compared transfusion ratios of 1:1:1 and 2:1:1 of packed red blood cells: fresh frozen plasma: platelets without statistical difference in the mortality rate ${ }^{47}$. Another approach is goal-directed coagulation therapy, which proposes individualized transfusion management based on the results of viscoelastic tests ${ }^{42}$. When the coagulopathy disorders have been controlled, some patients may remain hypovolemic requiring additional fluids administration. They may also have myocardial dysfunction requiring inotropic support or a vasodilatation state needing vasopressor support ${ }^{48}$. The vasopressors improve the microvascular perfusion but also can compromise it if the hypovolemia persists. Therefore, the physician should always ensure blood volume ${ }^{49}$.

\section{Conclusion}

The severely injured trauma patient who undergoes damage control surgery and is admitted to the Intensive Care Unit should always have a comprehensive evaluation that allows the physician to identify all the physiological alterations and establish the resuscitation management goals. These strategies allow an early correction of trauma-induced coagulopathy and hypoperfusion increasing the likelihood of survival. 


\section{References}

1. Rotondo MF, Schwab CW, McGonigal MD, Phillips GR 3rd, Fruchterman TM, Kauder DR, et al. \&apos;Damage control\&apos;: an approach for improved survival in exsanguinating penetrating abdominal injury. J Trauma. 1993; 35: 375-382. Doi: 10.1097/00005373199309000-00008.

2. Shapiro MB, Jenkins DH, Schwab CW, Rotondo MF. Damage control: collective review. J Trauma. 2000; 49: 969-978. Doi: 10.1097/00005373-200011000-00033.

3. Scalea TM, Boswell SA, Scott JD, Mitchell KA, Kramer ME, Pollak AN. External fixation as a bridge to intramedullary nailing for patients with multiple injuries and with femur fractures: damage control orthopedics. J Trauma. 2000; 48: 613-621. Doi: 10.1097/00005373-200004000-00006.

4. Rotondo MF, Bard MR. Damage control surgery for thoracic injuries. Injury. 2004; 35: 649 654. Doi: 10.1016/j.injury.2004.03.002.

5. Tien HC, Spencer F, Tremblay LN, Rizoli SB, Brenneman FD. Preventable deaths from hemorrhage at a level I Canadian trauma center. J Trauma. 2007; 62(1): 142-146. Doi: 10.1097/01.ta.0000251558.38388.47.

6. Brohi K, Singh J, Heron M, Coats T. Acute traumatic coagulopathy. J Trauma. 2003; 54(6): 1127-1130. Doi: 10.1097/01.TA.0000069184.82147.06.

7. Djaldetti M, Fishman P, Bessler H, Chaimoff C. $\mathrm{pH}$-induced platelet ultrastructural alterations. A possible mechanism for impaired platelet aggregation. Arch Surg. 1979; 114: 707-710. Doi: 10.1001/archsurg.1979.01370300061009.

8. Thorsen K, Ringdal KG, Strand K, Soreide E, Hagemo J, Soreide K. Clinical and cellular effects of hypothermia, acidosis and coagulopathy in major injury. Br J Surg. 2011; 98: 894-907. Doi: 10.1002/bjs.7497.

9. Lier H, Krep H, Schroeder S, Stuber F. Preconditions of hemostasis in trauma: a review. The influence of acidosis, hypocalcemia, anemia, and hypothermia on functional hemostasis in trauma. J Trauma. 2008; 65(4): 951-960. Doi: 10.1097/TA.0b013e318187e15b.

10. Rutherford EJ, Morris JA Jr, Reed GW, Hall KS. Base deficit stratifies mortality and determines therapy. J Trauma. 1992; 33: 417-423. Doi: 10.1097/00005373-199209000-00014.

11. Jurkovich GJ, Greiser WB, Luterman A, Curreri PW. Hypothermia in trauma victims: an ominous predictor of survival. J Trauma. 1987; 27: 1019-1024. Doi: 10.1097/00005373-198709000-00011.

12. Johnston TD, Chen Y, Reed RL. Functional equivalence of hypothermia to specific clotting factor deficiencies. J Trauma. 1994; 37: 413- 417 Doi: 10.1097/00005373-199409000-00014.

13. Kempainen RR, Brunette DD. The evaluation and management of accidental hypothermia. Respir Care. 2004; 49: 192-205. 
14. Kurz A, Sessler DI, Lenhardt R. Perioperative normothermia to reduce the incidence of surgical-wound infection and shorten hospitalization. Study of Wound Infection and Temperature Group. N Engl J Med. 1996; 334: 1209-1215. Doi: 10.1056/ NEJM199605093341901.

15. Seamon MJ, Wobb J, Gaughan JP, Kulp H, Kamel I, Dempsey DT. The effects of intraoperative hypothermia on surgical site infection: an analysis of 524 trauma laparotomies. Ann Surg. 2012; 255: 789-795. Doi: 10.1097/SLA.0b013e31824b7e35.

16. Hoffman M, Monroe DM. Coagulation 2006: a modern view of hemostasis. Hematol Oncol Clin North Am. 2007; 21: 1-11. Doi: 10.1016/j.hoc.2006.11.004.

17. Eberst ME, Berkowitz LR. Hemostasis in renal disease: pathophysiology and management. Am J Med. 1994; 96: 168 -179. Doi: 10.1016/0002-9343(94)90138-4.

18. Varon D, Dardik R, Shenkman B, Kotev-Emeth S, Farzame N, Tamarin I, et al. A new method for quantitative analysis of whole blood platelet interaction with extracellular matrix under flow conditions. Thromb Res. 1997; 85: 283-294. Doi: 10.1016/S0049-3848(97)00014-5

19. McLoughlin TM, Fontana JL, Alving B, Mongan PD, Bunger R. Profound normovolemic hemodilution: hemostatic effects in patients and in a porcine model. Anesth Analg. 1996; 83: 459-465. Doi: 10.1213/00000539-199609000-00003.

20. Hardy JF, de Moerloose P, Samama M. Massive transfusion and coagulopathy: pathophysiology and implications for clinical management. Can J Anesth. 2004; 51: 293-310. Doi: 10.1007/BF03018233.

21. Spahn DR. Hypocalcemia in trauma: frequent but frequently undetected and underestimated. Editorial. Crit Care Med. 2005; 33: 2124 -2125. Doi: 10.1097/01. CCM.0000174479.32054.3D.

22. Fukuda T, Nakashima Y, Harada M, Toyoshima S, Koshitani O, Kawaguchi Y, et al. Effect of whole blood clotting time in rats with ionized hypocalcemia induced by rapid intravenous citrate infusion. J Toxicol Sci. 2006;31: 229-234. Doi: 10.2131/jts.31.229.

23. Vivien B, Langeron O, Morell E, Devilliers C, Carli PA, Coriat P, et al. Early hypocalcemia in severe trauma. Crit Care Med. 2005; 33: 1946 -1952. Doi: 10.1097/01. CCM.0000171840.01892.36.

24. Barry GD. Plasma calcium concentration changes in hemorrhagic shock. Am J Physiol. 1971; 220: 874-879. Doi: 10.1152/ajplegacy.1971.220.4.874.

25. Hastbacka J, Pettila V. Prevalence and predictive value of ionized hypocalcemia among critically ill patients. Acta Anaesthesiol Scand. 2003; 47: 1264-1269 Doi: 10.1046/j.13996576.2003.00236.x.

26. Barbee RW, Reynolds PS, Ward KR. Assessing shock resuscitation strategies by oxygen debt repayment. Shock. 2010; 33: 113-122. Doi: 10.1097/SHK.0b013e3181b8569d 
27. Wang CH, Hsieh WH, Chou HC, Huang YS, Shen JH, Yeo YH, et al. Liberal versus restricted fluid resuscitation strategies in trauma patients: a systematic review and metaanalysis of randomized controlled trials and observational studies. Crit Care Med. 2014; 42(4): 954-961 Doi: 10.1097/CCM.0000000000000050.

28. Guly HR, Bouamra O, Spiers M, Dark P, Coats T, Lecky FE; Trauma Audit and Research Network. Vital signs and estimated blood loss in patients with major trauma: testing the validity of the ATLS classification of hypovolaemic shock. Resuscitation. 2011; 82(5): 556-559 Doi: 10.1016/j.resuscitation.2011.01.013.

29. Abou-Khalil B, Scalea TM, Trooskin SZ, Henry SM, Hitchcock R. Hemodynamic esponses to shock in young trauma patients: need for invasive monitoring. Crit Care Med. 1994; 2: 633639. Doi: 10.1097/00003246-199404000-00020

30. Scalea TM, Maltz S, Yelon J, Trooskin SZ, Duncan AO, Sclafani SJ. Resuscitation of multiple trauma and head injury: role of crystalloid fluids and inotropes. Crit Care Med. 1994; 22: 1610-1615. Doi: 10.1097/00003246-199410000-00017

31. Meregalli A, Oliveira RP, Friedman G. Occult hypoperfusion is associated with increased mortality in hemodynamically stable, high-risk, surgical patients. Crit Care. 2004; 8: R60-R65. Doi: $10.1186 /$ cc2423

32. Blow O, Magliore L, Claridge JA, Butler K, Young JS. The golden hour and the silver day: detection and correction of occult hypoperfusion within 24 hours improves outcome from major trauma. J Trauma. 1999; 47: 964-969. Doi: 10.1097/00005373-199911000-00028

33. Davis JW, Shackford SR, Mackersie RC, Hoyt DB. Base deficit as a guide to volume resuscitation. J Trauma. 1988; 28: 1464-1467. Doi: 10.1097/00005373-198810000-00010

34. Abramson D, Scalea TM, Hitchcock R, Trooskin SZ, Henry SM, Greenspan J. Lactate clearance and survival following injury. J Trauma. 1993; 35: 584-588. discussion 588-9. Doi: 10.1097/00005373-199310000-00014

35. McNelis J, Marini CP, Jurkiewicz A, Szomstein S, Simms HH, Ritter G, Nathan IM. Prolonged lactate clearance is associated with increased mortality in the surgical intensive care unit. Am J Surg. 2001; 182: 481-485. Doi: 10.1016/S0002-9610(01)00755-3

36. Stensballe J, Henriksen HH, Johansson PI. Early haemorrhage control and management of trauma-induced coagulopathy: the importance of goal-directed therapy. Curr Opin Crit Care. 2017; 23(6): 503-510. Doi: 10.1097/MCC.0000000000000466

37. Ostrowski SR, Henriksen HH, Stensballe J, Gybel-Brask M, Cardenas JC, Baer LA, et al. Sympathoadrenal activation and endotheliopathy are drivers of hypocoagulability and hyperfibrinolysis in trauma: a prospective observational study of 404 severely injured patients. J Trauma Acute Care Surg. 2017; 82: 293-301. Doi: 10.1097/TA.0000000000001304 
38. Johansson PI, Henriksen HH, Stensballe J, Stensballe J, Gybel-Brask M, Cardenas JC, et al. Traumatic endotheliopathy: a prospective observational study of 424 severely injured patients. Ann Surg. 2017; 265: 597-603. Doi: 10.1097/SLA.0000000000001751

39. Shaz BH, Winkler AM, James AB, Hillyer CD, MacLeod JB. Pathophysiology of early traumainduced coagulopathy: emerging evidence for hemodilution and coagulation factor depletion. J Trauma. 2011; 70: 1401-1407 Doi: 10.1097/TA.0b013e31821266e0

40. Fries D, Innerhofer P, Schobersberger W. Time for changing coagulation management in trauma-related massive bleeding. Curr Opin Anaesthesiol. 2009; 22: 267-274. Doi: 10.1097/ ACO.0b013e32832678d9

41. Shere-Wolfe RF, Galvagno SM Jr, Grissom TE. Critical care considerations in the management of the trauma patient following initial resuscitation. Scand J Trauma Resusc Emerg Med. 2012; 20: 68. Doi: 10.1186/1757-7241-20-68

42. Schochl H, Maegele M, Solomon C, Gorlinger K, Voelckel W. Early and individualized goal-directed therapy for trauma-induced coagulopathy. Scand J Trauma Resusc Emerg Med. 2012; 20: 15. Doi: 10.1186/1757-7241-20-15

43. Wray JP, Bridwell RE, Schauer SG, Shackelford SA, Bebarta VS, Wright FL, et al. The diamond of death: Hypocalcemia in trauma and resuscitation. Am J Emerg Med. 2021; 41: 104-109 Doi: 10.1016/j.ajem.2020.12.065

44. Cannon JW. Hemorrhagic shock. N Engl J Med. 2018; 378(4): 370-379. Doi: 10.1056/ NEJMra1705649

45. Curry N, Brohi K. Surgery in traumatic injury and perioperative considerations. Semin Thromb Hemost. 2020; 46(1): 73-82. Doi: 10.1055/s-0039-1697932

46. Schafer N, Driessen A, Frohlich M, Stürmer EK, Maegele M; TACTIC partners. Diversity in clinical management and protocols for the management of major bleeding of trauma patients across European level 1 Trauma Centres. Scand J Trauma Resusc Emerg Med. 2015; 23: 74 Doi: 10.1186/s13049-015-0147-6

47. Holcomb JB, Tilley BC, Baraniuk S, Fox EE, Wade CE, Podbielski JM, et al. Transfusion of plasma, platelets, and red blood cells in a 1:1:1 vs a 1:1:2 ratio and mortality in patients with severe trauma: the PROPPR randomized clinical trial. JAMA. 2015; 313(05): 471-482 Doi: 10.1001/jama.2015.12

48. Abou-Khalil B, Scalea TM, Trooskin SZ, Henry SM, Hitchcock R. Hemodynamic responses to shock in young trauma patients: need for invasive monitoring. Crit Care Med. 1994; 22: 633-639. Doi: 10.1097/00003246-199404000-00020

49. Sperry JL, Minei JP, Frankel HL, West MA, Harbrecht BG, Moore EE, et al. Early use of vasopressors after injury: caution before constriction. J Trauma. 2008; 64: 9-14. Doi: 10.1097/ TA.0b013e31815dd029. 